\title{
18. IN SITU STRESSES IN THE LAU BASIN AND TONGA FOREARC (SOUTHWEST PACIFIC)1
}

\author{
C.J. MacLeod ${ }^{2}$ and C.E. Pratt ${ }^{3}$
}

\begin{abstract}
Unequal stress concentrations around boreholes may lead to localized failure and hence elongation of the borehole wall perpendicular to the maximum horizontal compressive stress direction. In this paper we have made an assessment of the horizontal in situ lithospheric stress directions in the Lau backarc basin and Tonga forearc using downhole logging data from Ocean Drilling Program (ODP) Leg 135. We derive the cross-sectional shapes of the Leg 135 boreholes from Formation MicroScanner (FMS) caliper data, and then analyze these data to isolate stress-induced borehole elongations.

The results from four sites in the Tonga forearc and central Lau Basin suggest that the maximum horizontal compressive stress direction is approximately north-south; that is, broadly parallel to the trend of the forearc and backarc spreading axis. This is in accord with the geological evidence that the forearc platform and outer slope are actively in extension, but it contrasts directly with the predominantly trench-normal, maximum, in situ stress directions measured from forearcs above other subduction zones (e.g., Japan, the Aleutians, and the Hellenic Arc). We argue that this difference between the Tonga and these other subduction systems relates to the degree of mechanical coupling across the principal subduction (plate boundary) fault: recent modeling of the dynamics of such systems has shown that the forearc should be in extension if the coupling is very weak, that is, if the subduction fault is acting as a free surface. If there is strong or moderate coupling, however, then compression or a gradient from compression to extension should result.

Two sites drilled in the western Lau Basin have borehole elongation directions that are perpendicular to those of the Tonga forearc and central Lau Basin. If real, the results from these sites suggest a $90^{\circ}$ change in the orientation of the maximum stress direction across the Lau backarc basin; it is possible, however, that they are being affected by local perturbations of the stress field and have little regional significance.
\end{abstract}

\section{INTRODUCTION}

\section{In Situ Stress Measurements from Boreholes}

It has long been recognized that unequal horizontal stress concentrations around boreholes may induce localized failure, resulting in spalling (and hence elongation) of the borehole wall perpendicular to the direction of maximum horizontal compressive stress $S_{H \max }$ (e.g., Bell and Gough, 1979, 1983; Gough and Bell, 1981; Zoback et al., 1985). Use of well-log tools such as the four-arm dipmeter and Borehole Televiewer (BHTV) has shown that the azimuths of these spalled zones, termed "breakouts" by Babcock (1978), are typically consistent, not only within individual wells but often between wells on the scale of an entire oilfield (e.g., Bell and Gough, 1979) or even across much of a continent (e.g., Zoback and Zoback, 1980; Fordjor et al., 1983; Gough, 1984; Zoback, 1992). This is taken to suggest that, in general, the in situ stresses measured relate to regional lithospheric stresses (e.g., Bell and Gough, 1979; Zoback and Zoback, 1980; although see below). Theoretical (e.g., Gough and Bell, 1981; Bell and Gough, 1983) and laboratory studies (Haimson and Herrick, 1986), together with data from the ultrasonic BHTV (e.g., Zoback et al., 1985), have shown that borehole failure is a result of localized compressive shear failure, with spalling along flat conjugate shear planes giving rise to a shallow triangular form to the breakouts on either side of the borehole.

Except for such special techniques as hydrofracturing experiments (Haimson and Fairhurst, 1967, 1970), in situ stress information can be obtained either from the four-arm dipmeter and its successor, the FMS, or from the BHTV. The four-arm dipmeter and the FMS measure resistivity variations on four orthogonal pads that are pressed against the borehole wall by means of two pairs of linked sprung calipers. With

\footnotetext{
'Hawkins, J., Parson, L., Allan, J., et al., 1994. Proc. ODP. Sci. Results, 135: College Station, TX (Ocean Drilling Program).

${ }^{2}$ Institute of Oceanographic Sciences, Brook Road, Wormley, Surrey GU8 5UB, United Kingdom.

${ }^{3}$ Mineral Resources Department, Private Mail Bag, Suva, Fiji.
}

the four-arm dipmeter, information on the well-bore elongation is derived simply from the difference between the two orthogonal hole diameters, and the orientation of one of the pads, with depth. The same is basically true for the more sophisticated FMS, although further information may be obtained from examination of the electrical "images" that it generates of the borehole wall. The FMS has an array of 16 individual resistivity sensors on each pad that are processed to give an electrical image (with vertical resolution of $\sim 5 \mathrm{~mm}$ ) of that portion of the borehole wall in contact with the pads (approximately $20 \%$ per pass for a 12-in. diameter hole with the ODP tool; Ekstrom et al., 1986). Breakouts may occasionally be recognized on these images, typically appearing as dark (i.e., low resistivity), near-vertical cracks (Fig. 1). They are easily confused with vertical faults or joints, but they should not displace bedding or other features and, ideally, should be present on images from two opposite pads $180^{\circ}$ apart.

The BHTV, in contrast to the FMS, yields sonic images of the entire borehole wall (Zemanek et al., 1970), from which detailed information on the size and shape of breakouts can be readily obtained. This information is sufficient to allow calculations to be made not only of the orientations but also of the magnitudes of crustal stresses (Zoback et al., 1985; Moos and Zoback, 1990; Vernick and Zoback, 1992; Zoback and Healy, 1992).

Despite the less detailed nature of the borehole elongation data obtained from dipmeter or FMS calipers, comparative studies of downhole hydrofracturing experiments (Hickman et al., 1985), BHTV (Zoback et al., 1985) and four-arm dipmeter (Plumb and Hickman, 1985) data from the same wells show that, if certain criteria are met (see below), borehole elongation directions obtained from the dipmeter and FMS calipers are indeed the same as the BHTV breakout orientations and are, in turn, parallel to the direction of least horizontal compressive stress derived from the hydrofracturing data (Plumb and Hickman, 1985). These findings justify the wider use of dipmeter/FMS data in studies of in situ stresses in boreholes, the advantage of which being the routine use of the four-arm dipmeter and (nowadays) the FMS in the petroleum industry and, hence, the widespread availability of well-log data for analysis. 
ORIENTATION NORTH

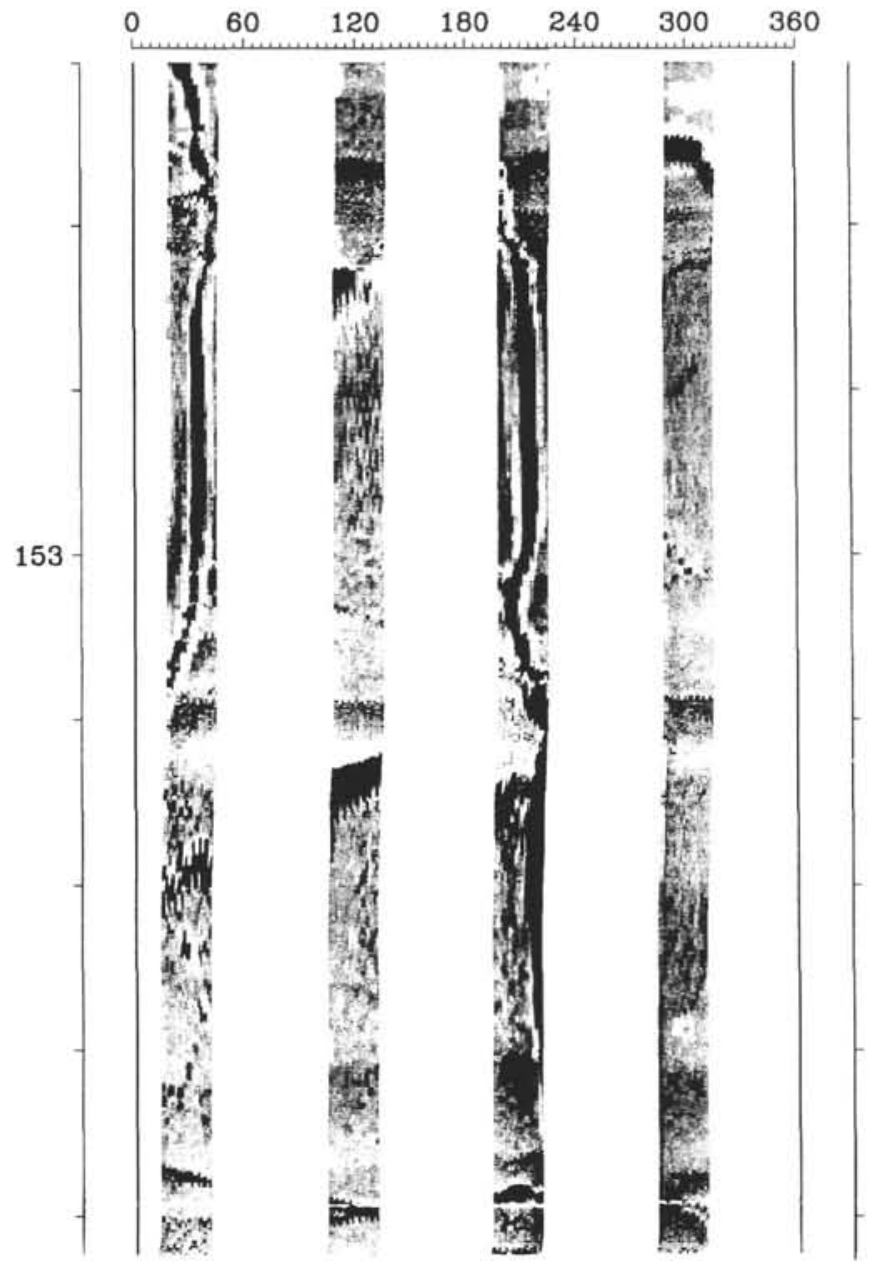

Figure 1. Vertical, anastomosing fractures on an FMS record from Hole 834B. interpreted as a stress-induced breakout. The fractures should not offset bedding significantly and (as here) ideally should appear $180^{\circ}$ apart on two pads.

\section{The Lau Basin}

The Lau Basin is a trapezoidal-shaped active backarc marginal basin in the southwestern Pacific, forming at the leading edge of the Indo-Australian Plate as it overrides the subducting Pacific Plate. The basin lies between a north-trending remnant arc (the Lau Ridge) to the west and a north-northeast-trending active island arc/forearc complex (the Tonga Ridge) in the east (Fig. 2). It is now assumed (Parson, Hawkins, Allan, et al,, 1992; Parson et al., this volume) that the opening history of the basin involved a protracted period of attenuation and rifting of the original Lau/Tonga protoarc before initiation of the backarc seafloor spreading known to be active at the present day (e.g., Collier and Sinha, 1990; Parson et al., 1990). Recent studies (Parson and Hawkins, this volume) suggest that the southern segment of the backarc spreading axis (now represented by the Eastern Lau Spreading Center) formed at approximately $5.5 \mathrm{Ma}$ in the vicinity of the Peggy Ridge and propagated southward through the attenuated arc crust, "unzipping" the Lau and Tonga ridges and rotating the Tonga Ridge clockwise as it did so (MacLeod et al., 1992, and this volume; Sager et al., this volume; Fig. 2). This arc-rifting process is continuing today at the Valu Fa Ridge. In the past 1-2 m.y., a second propagating rift (the Central Lau Spreading Center) has formed and is moving rapidly southward through the existing backarc crust, at the expense of the Eastern Lau Spreading Center (Parson et

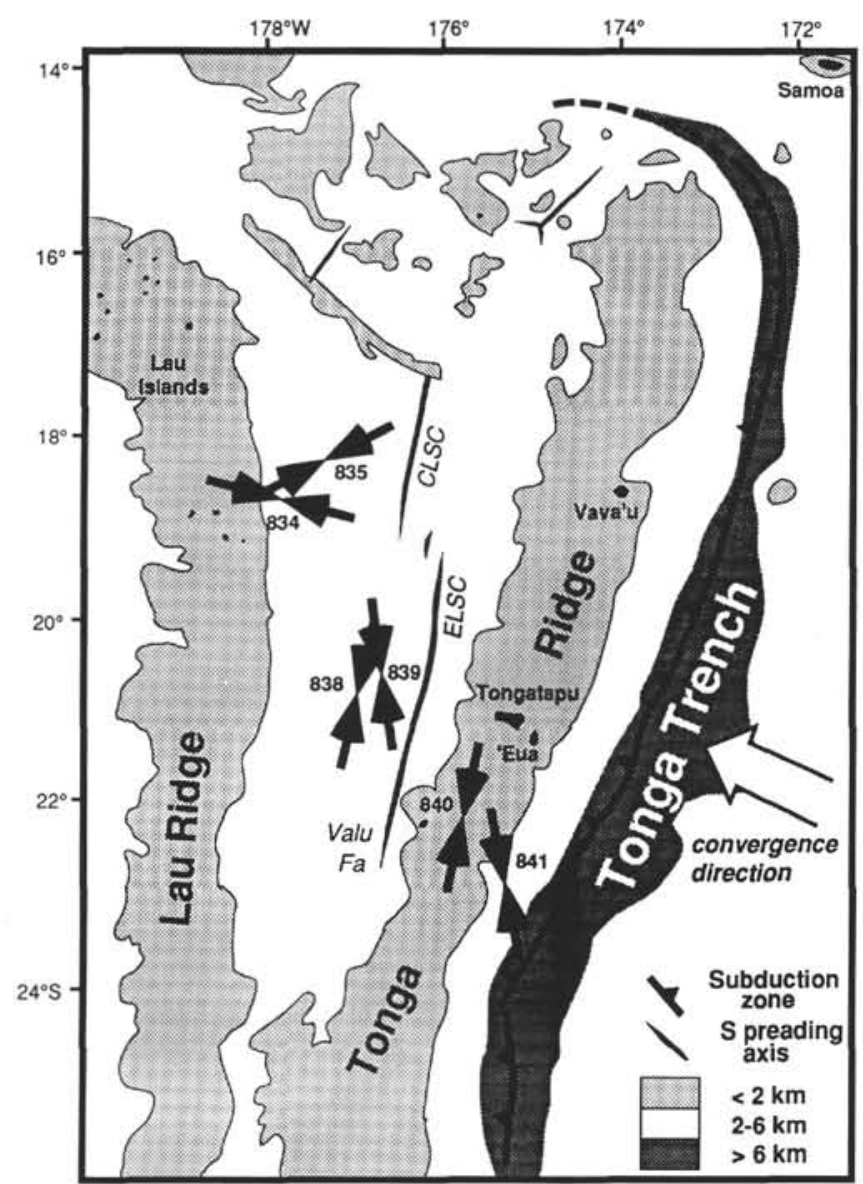

Figure 2. The Lau backarc basin, showing the location of sites drilled on Leg 135 , and the orientation of the maximum horizontal compressive stress $S_{H \max }$, as deduced from this study. CLSC $=$ Central Lau Spreading Center, and ELSC = Eastern Lau Spreading Center.

al., 1990; Parson and Hawkins, this volume; Fig. 2). Bathymetric, sidescan sonar and ODP drilling data (Parson et al., 1990; Parson, Hawkins, Allan, et al., 1992) suggest that a "pseudofault" boundary exists within the western half of the Lau Basin, between low-relief crust formed by seafloor spreading at the Eastern Lau Spreading Center to the east and attenuated arc crust, characterized by a horstand-graben topography with relief of up to $1600 \mathrm{~m}$, to the west (Parson and Hawkins, this volume; Parson et al., this volume).

Leg 135 drilled six sites (834-839) in this western part of the Lau Basin, between the Lau Ridge and the active Lau spreading centers, and two sites (840-841) on the Tonga platform/forearc (Fig. 2). Of the backarc sites, Parson and Hawkins (this volume) and Parson et al. (this volume) have suggested that the basins within which Sites 834,838 , and 839 were drilled fall to the west of the pseudofault boundary (i.e., in rifted arc-type basement), that Site 836 lies to the east of it, within crust derived from the Eastern Lau Spreading Center, and that Sites 835 and 837 lie very close to, but probably slightly west of, the boundary.

The presently active island arc chain, the Tofua Arc, lies at the western edge of the north-northeast-trending forearc platform of the Tonga Ridge. The platform appears to be composed of the products of arc-related volcanism that range back at least to the middle Eocene. This age is inferred from the middle Eocene sediments that overlie a low-K subaerial rhyolitic arc complex encountered at a present-day depth of approximately $5.4 \mathrm{~km}$ at Site 841 , on the inner trench slope of the Tonga forearc (Parson, Hawkins, Allan, et al., 1992). Based upon seismic evidence (e.g., Herzer and Exon, 1985; Tappin et al., in press), sidescan sonar data (MacLeod and Lothian, this volume) and 
structural evidence from Site 841 (MacLeod, this volume) for recent trench-parallel normal faulting, it is apparent that much of the Tonga forearc is actively in extension.

\section{METHODOLOGY}

Sites $834,835,838,839,840$, and 841 were each logged with two passes of the FMS. Holes at Sites 836 and 837 were too shallow for logging to be attempted. The BHTV was run at Sites 834 and 839 , but instrument failure unfortunately rendered the data useless; therefore, our analysis of borehole breakouts from Leg 135 has been made using the FMS data only.

Enlargement of the borehole can have several causes in addition to the in situ stress. Poorly consolidated material is commonly washed out, so as to enlarge the borehole in all directions; this may, however, be superimposed upon a breakout and therefore may potentially still give information on the stress direction. Significant deviation of the borehole from the vertical forces the tool toward the lower side of the borehole and can result in caliper readings of less than the bit size; rotation of the tool is inhibited, and drill-pipe wear of the borehole ("key seating") is greatly enhanced, leading to anomalous borehole elongation. Intersection of fractures with the borehole can also result in washout and elongation parallel to the fault strike rather than the stress direction; and poorly consolidated dipping sediments interbedded with more competent strata can have a similar effect. To isolate true breakouts in a borehole it is therefore necessary to identify and account for such anomalous borehole elongations. This has led previous authors (e.g., Fordjor et al., 1983; Plumb and Hickman, 1985; Springer, 1987; Evans and Brereton, 1990) to develop various "detection thresholds" or "recognition criteria" in an attempt to distinguish them. These have been followed in the present study, within the limitations of the data available, and may be summarized as follows:

1. The tool must stop rotating. In a perfectly smooth, in-gauge hole the FMS or dipmeter tool will slowly rotate clockwise as it is dragged upward because of the torque in the cable. When a pad encounters a breakout it should "lock in" to it, and the pad azimuth should therefore remain constant for some distance. For this study, caliper measurements were made every 6 in. $(0.1524 \mathrm{~m})$ and a minimum length of four data points, or $60 \mathrm{~cm}$, was imposed.

2. The difference between the two calipers must be greater than $0.25 \mathrm{in}$. This is considered to be the minimum depth of breakout that the tool can lock in to (Plumb and Hickman, 1985), and is constrained by the physical size of the FMS or dipmeter pads.

3. The calipers should always be greater than the bit size (here 9.875 in. diameter throughout), so as to eliminate the effects of tool eccentricity; furthermore, the long axis of borehole elongation should not coincide consistently with the direction of deviation of the borehole, so as to account for the possible effects of key seating. Evans and Brereton (1990) found anomalous borehole elongation from key seating and tool eccentricity to be significant only in boreholes that were deviated by more than $10^{\circ}$. Hole deviation data from the Leg 135 boreholes show that only Hole $834 \mathrm{~B}$ is deviated by more than $2.5^{\circ}$ (maximum $=4.5^{\circ}$, average $=2.2^{\circ}$ ). The average deviation of the other holes is in the range $0.5^{\circ}-1.6^{\circ}$; therefore, it is thought unlikely that key seating and the effects of tool eccentricity are significant with the Leg 135 data. This is discussed below, where appropriate, when considering the data site by site.

4. If the hole is washed out, then the smaller of the caliper readings should still be close to bit size, or exhibit less variation than the larger. With the Leg 135 data virtually all of the boreholes exhibited some degree of washout, for which reason an upper limit of $12.5 \mathrm{in}$. was set for the size of the smaller caliper (although see the discussion of Site 838 below). The larger caliper reading should be less than the maximum caliper width (here, 15.25 in.).

We derived algorithms to eliminate data that did not fulfil the above criteria and to take the azimuth of the two hole diameter measurements rather than that of the reference pad, "Pad 1" or caliper "Cl". Because the borehole must be assumed to be symmetrical, all orientation data have been converted to fall within a $180^{\circ}$ range, here between $180^{\circ}$ and $360^{\circ}$. The algorithms were applied to caliper data from the two passes from each of the logged sites. These data are discussed site by site below.

\section{LEG 135 DRILL SITES}

\section{Site 835}

Site 835 is situated on the eastern side of an $\sim 10$-km-wide, fault-bounded basin. Approximately $2 \mathrm{~km}$ to the east of the site is a steep 1300-m-high scarp that trends slightly west of north $\left(\sim 355^{\circ}\right.$; Parson et al., this volume). Sediments of Pliocene (3.5 Ma: Rothwell et al., this volume) to Holocene age overlie igneous rocks at $155 \mathrm{~m}$ below seafloor (mbsf); Hole $835 \mathrm{~B}$ further penetrated lavas to a total depth of 183 mbsf.

Two passes of the FMS yielded data between 75 and 171 mbsf. Borehole deviation is less than $1^{\circ}$ throughout this interval (Fig. 3A). Caliper logs from both Runs 1 and 2 show very uniform hole conditions between 90 and 160 mbsf (i.e., within the sedimentary sections of the borehole). In particular, between 90 and 120 mbsf, the hole is markedly elliptical, with almost constant pad azimuth (Fig. 3B). Occasional increases of both calipers correspond with low resistivity zones on the FMS images; at $140 \mathrm{mbsf}$, for example, an 80-cm-thick, low-resistivity zone defines a north-striking, west-dipping plane that almost certainly represents a minor fault zone. This parallels the orientation of joints in lavas recovered from Hole 835B (reoriented using paleomagnetism: MacLeod, unpubl. data; Parson, Hawkins, Allan, et al., 1992) and is parallel to the overall trend of the graben within which Site 835 is situated.

The results of applying the algorithms or "filters" described above to the data are shown in Figures 3C and 3D. For Run 1, $60.66 \mathrm{~m}$ of the borehole satisfied the stress-induced breakout criteria, and 51.51 $\mathrm{m}$ for FMS Run 2. An extremely well-defined borehole elongation direction was isolated, with a maximum direction lying between $330^{\circ}$ and $335^{\circ}$ for the two passes combined (Fig. 3F). On the FMS images from Hole 834B, we recognized 32 low-resistivity, vertical features up to $1 \mathrm{~m}$ long that we interpret as breakouts (Fig. 1; Run 1: $N=13$; Run 2: $N=19$ ); these have similar, but less well-constrained maxima of $330^{\circ}$ for both runs (Figs. 3C-3D). In the present instance the unfiltered, raw azimuthal data (taken for the larger pad, be it caliper $\mathrm{C} 1$ or $\mathrm{C} 2$ ) also shows a well-developed northwest to north-northwest preferred elongation, but with greater dispersion (Fig. 3E).

\section{Site 834}

Site 834 is located in a small ( $\sim 8 \mathrm{~km}$ wide) basin, trending north or a few degrees west of north, lying approximately $100 \mathrm{~km}$ east of the axis of the remnant arc of the Lau Ridge. Several small ridges and troughs within the basin are interpreted as fault-controlled horsts and grabens, respectively (Parson et al., this volume). Igneous rocks were first encountered at $112 \mathrm{mbsf}$, and are intercalated with sediments to a depth of $164 \mathrm{mbsf}$; thereafter, only lavas were drilled to a total depth (Hole 834B) of $435 \mathrm{mbsf}$. The oldest sediments are of upper Miocene age ( $5.5 \mathrm{Ma})$. Hole deviation is greater than for any of the other sites, reaching a maximum of $4.5^{\circ}$ at the lava-sediment interface and declining thereafter, and with the deviation direction being between northeast and east (Fig. 4A). However, this direction is not parallel to the mean borehole elongation direction of $\sim 200^{\circ}$ (see below), and it is therefore considered unlikely that the deviation is responsible for any anomalous elongation.

In general, basalt recovered from the upper igneous units (Units 2 and 5) was relatively coherent and massive, with few chilled margins; in contrast, material from the lower igneous units was far more fragmentary, but with glassy chilled margins more commonly preserved. This has been taken to suggest that the upper units were 
A.

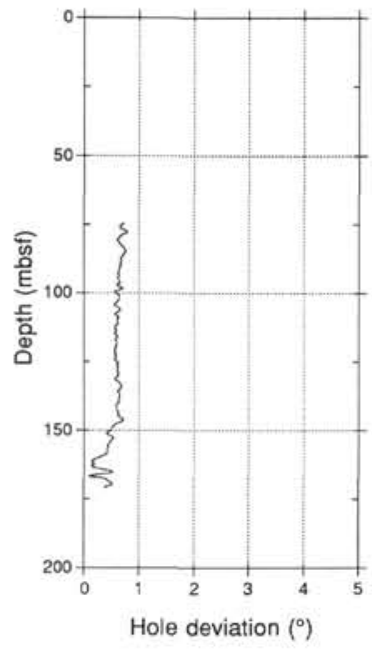

Hole 835B

Run 1

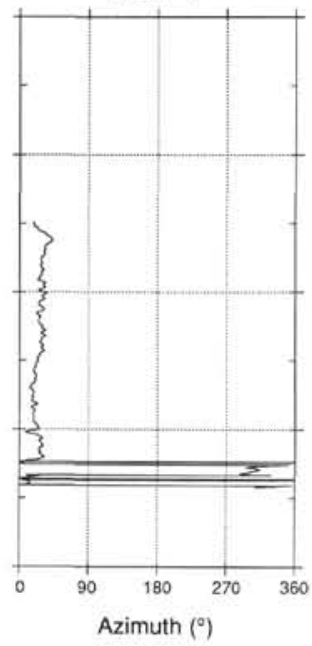

C. Hole 835B Run 1

- Borehole elongations

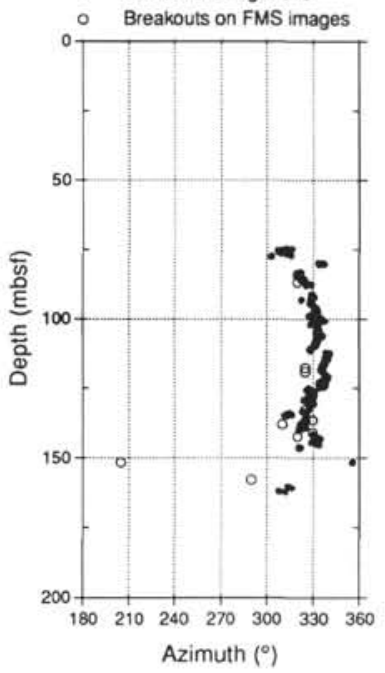

E. Site 835

Runs 1 and 2

Borehole elongation

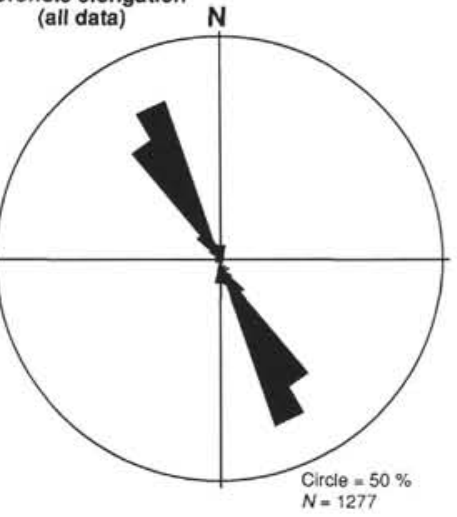

B. …....... $\mathrm{C}_{1}$

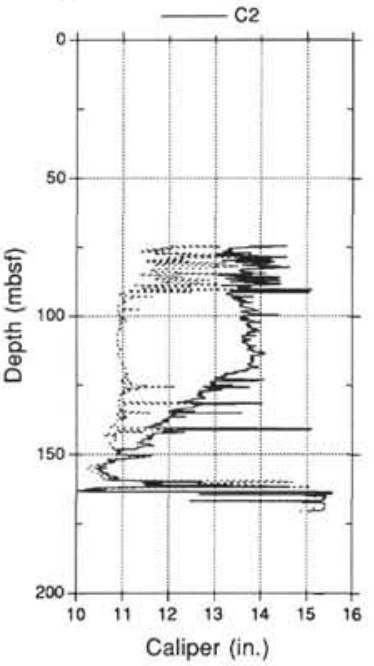

Hole 835B
Run 1

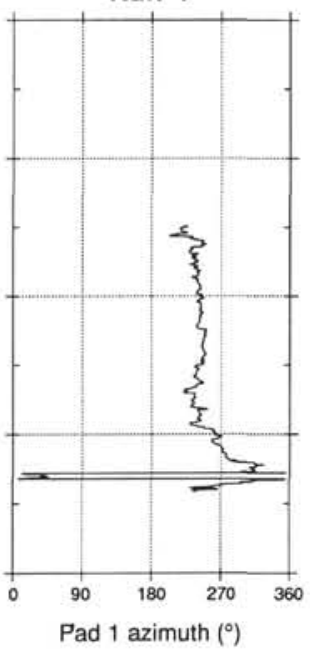

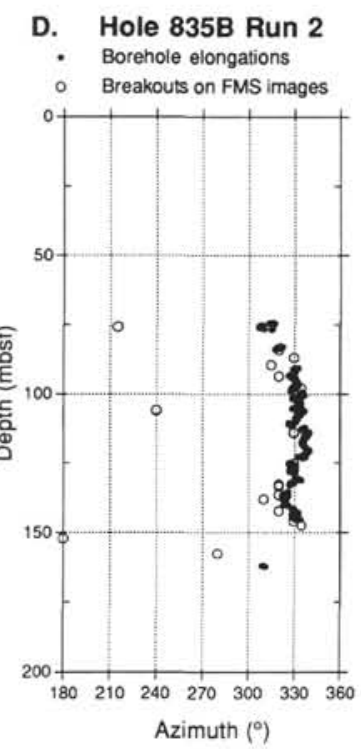

F.

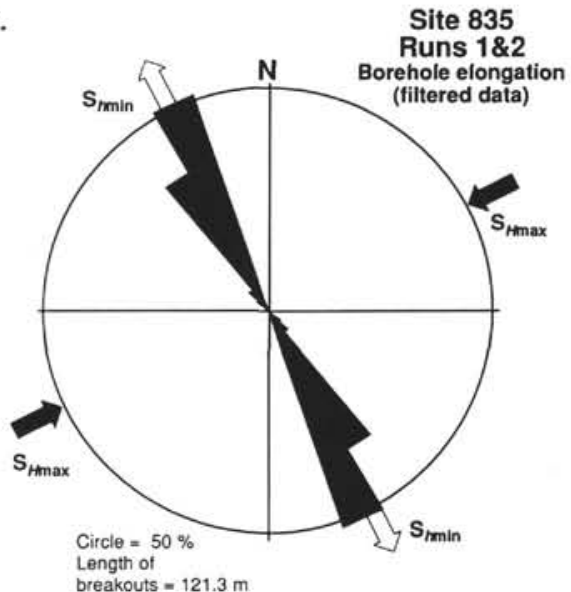

Figure 3. Borehole elongation data for Site 835. A. Hole deviation and azimuth vs. depth. B. Orthogonal calipers $\mathrm{Cl}$ and $\mathrm{C} 2$ and caliper $\mathrm{Cl}$ azimuth vs. depth, Run I. C-D. Filtered borehole elongation directions and breakout orientations from FMS images vs. depth, Runs I and 2, respectively. E. Rose diagram of unfiltered borehole elongation data. $N=$ number of discrete caliper measurements, taken every $0.1524 \mathrm{~m}$ throughout the logged interval of the borehole. F. Rose diagram of borehole elongation data filtered using standard filters, with the inferred maximum and minimum in situ stress orientations indicated by the arrows. 
A.

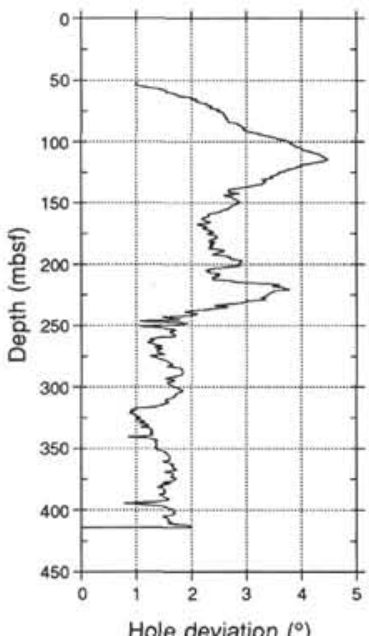

Hole deviation $\left({ }^{\circ}\right)$
Hole 834B

Run 1

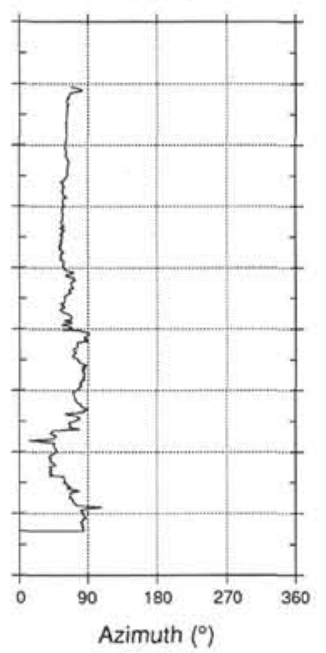

Azimuth $\left({ }^{\circ}\right)$

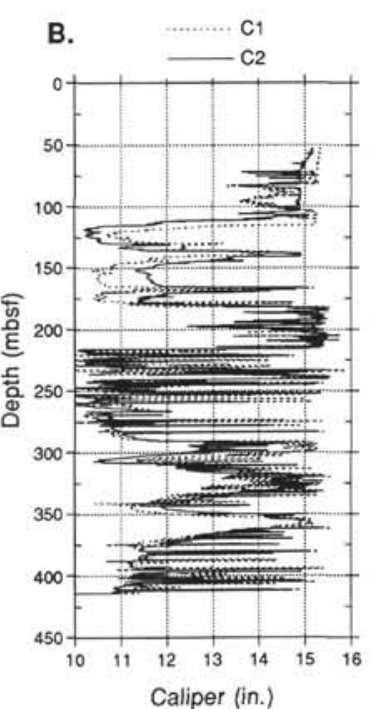

Hole 834B Run 1

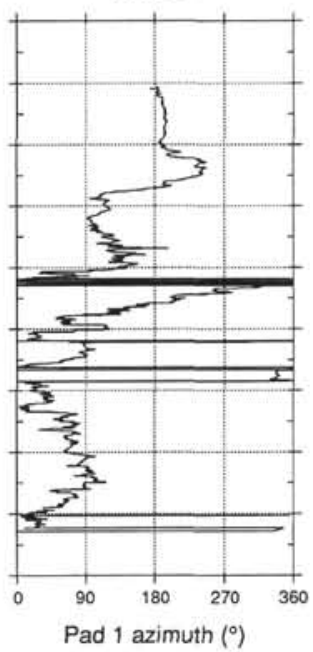

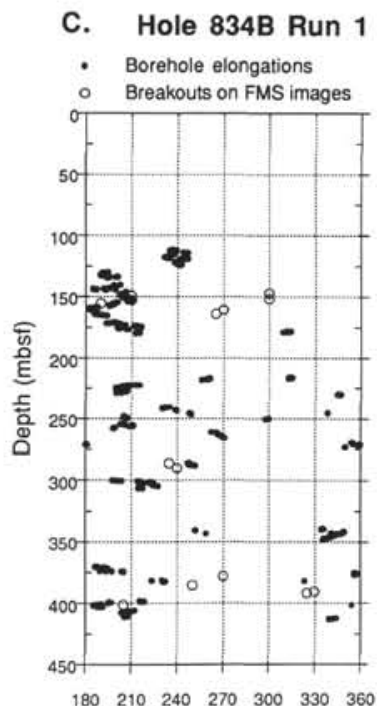

E. Site 834

Runs 1 and 2

Borehole elongation
(all data)

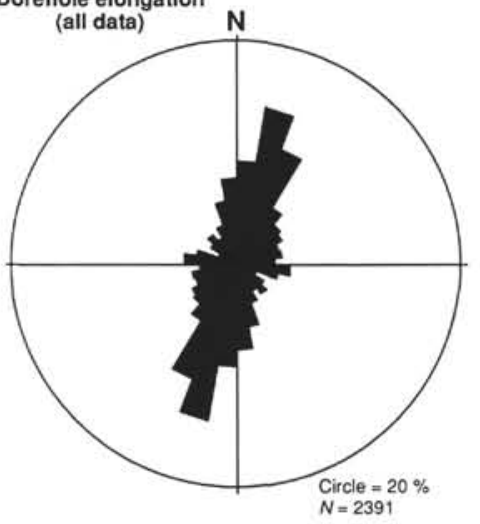

D. Hole 834B Run 2
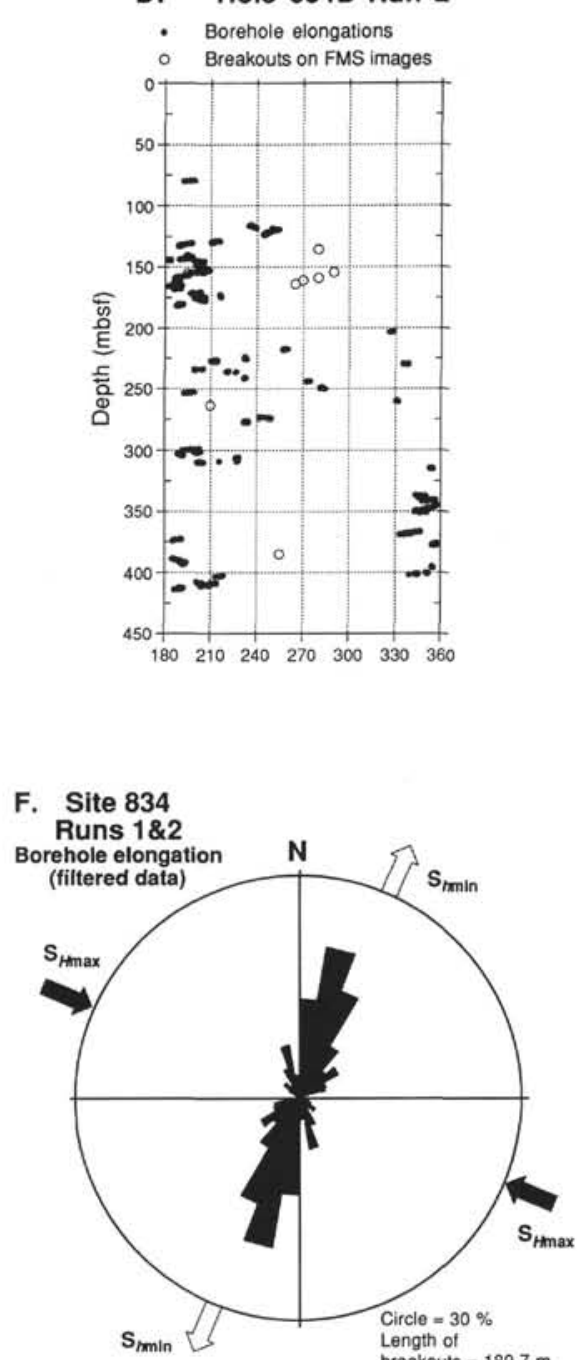

Figure 4. Borehole elongation data for Site 834. A. Hole deviation and azimuth vs. depth. B. Orthogonal calipers $\mathrm{Cl}$ and $\mathrm{C} 2$ and caliper $\mathrm{Cl}$ azimuth vs. depth, Run 1. C-D. Filtered borehole elongation directions and breakout orientations from FMS images vs. depth, Runs 1 and 2, respectively. E. Rose diagram of unfiltered borehole elongation data. $N=$ number of discrete caliper measurements, taken every $0.1524 \mathrm{~m}$ throughout the logged interval of the borehole. F. Rose diagram of borehole elongation data filtered using standard filters, with the inferred maximum and minimum in situ stress orientations indicated by the arrows. 
massive flows or sills (probably the former, on evidence from their standard log characteristics; MacLeod, unpubl. data; Parson, Hawkins, Allan, et al., 1992), and the lower units predominantly pillowed flows. The difference is reflected in the downhole log characteristics, including the FMS calipers, which all show far more coherent response in the range 112-164 mbsf than below (Fig. 4B; Parson, Hawkins, Allan, et al., 1992). Virtually all of the sedimentary sections of the borehole are severely washed out, such that the FMS calipers are at maximum extent (the sedimentary interbeds between $\sim 125$ and $165 \mathrm{mbsf}$ are clearly delineated). In the lower parts of the igneous section rapid oscillation of the calipers up to the tool maximum attests to the extreme rugosity of the hole (Fig. 4B).

Application of the breakout algorithms to these data results in the elimination of a large part of the logged interval (Figs. 4C-4D). Most of the surviving sections are in the massive igneous units described above, within which borehole conditions are demonstrably more stable; short sections in the lower part of the borehole, however, still fulfil the breakout criteria. These were checked manually and the validity of the algorithms' discrimination verified. Unfiltered borehole elongations show a preferred trend slightly to the east of north (Fig. 4E); filtering the data reinforces this preference, isolating a maximum direction between $195^{\circ}$ and $200^{\circ}$ (Fig. 4F).

\section{Site 839}

Sites 838 and 839 are both located in a northeast-trending basin within attenuated arc crust, some $55 \mathrm{~km}$ west of the Eastern Lau Spreading Center. The orientation of this fault-bounded basin contrasts with the regional north to north-northeast fabric, although a north-trending tectonic feature does occur, in the form of an upfaulted saddle that occupies the center of the basin and divides it into two parts (Parson, Hawkins, Allan, et al., 1992; Parson et al., this volume). Site 839 is situated in the northeastern part of the basin. Some $218 \mathrm{~m}$ of sediment were drilled (the oldest having an age of $\sim 1.9 \mathrm{Ma}$; Parson, Hawkins, Allan, et al., 1992) before igneous rocks were encountered. The total depth of Hole 839B was 517 mbsf, of which the interval from 81 to 467 mbsf was logged with the FMS. Hole deviation increases slightly downhole to a maximum of $1.5^{\circ}$ (Fig. 5A).

Although hole conditions were poor, unfiltered borehole elongations from both Runs 1 and 2 show a consistent east-northeast trend (Figs. 5B and 5E). Filtering the data emphasizes this, isolating a well-defined maximum direction between $255^{\circ}$ and $260^{\circ}$ (Figs. 5C, $5 \mathrm{D}$, and $5 \mathrm{~F}$ ). The FMS breakouts show a broad spread of orientations, but those from Run 1 in particular are predominantly east-trending, broadly parallel to the breakout direction inferred here from the borehole elongation.

\section{Site 838}

Site 838 lies in the southwestern part of the northeast-trending basin described above. Here $259 \mathrm{~m}$ of Upper Pliocene to Holocene sediments were drilled, igneous basement not being reached. The sedimentary sequence is dominated by thick proximal turbidites and unconsolidated pumiceous gravels; consequently hole conditions were poor and core recovery extremely low.

Two passes of the FMS were run between 57 and 229 mbsf. Hole deviation is minor (Fig. 6A), but much of Hole 838B is severely washed out, with both calipers being greater than 12 in. throughout (Fig. 6B). Unfiltered borehole elongation data show little preferred orientation to the maximum pad azimuth (Fig. 6E), and little apparent correspondence between the two passes (see below). Filtering of these data using the aforementioned recognition criteria excludes virtually all of the data (some $97.4 \%$ of Run 1 and $98.8 \%$ of Run 2), most failing on the criterion that the smaller caliper be greater than $12.5 \mathrm{in}$. Those data that are left ( $4.6 \mathrm{~m}$ of Run 1 and $2.1 \mathrm{~m}$ of Run 2), however, do show a broadly unimodal distribution, with maximum between $280^{\circ}$ and $285^{\circ}$ (Fig. 6F).
Although the remaining elongation data are relatively well clustered (Fig. 6F), we feel far less confident than we do for the other sites that this maximum direction relates to the minimum in situ stress direction $\left(S_{h \min }\right)$ at Site 838 , given the extremely small data set upon which we have had to base our estimate. We recognize that the filtering that we have applied is likely to have removed good borehole elongation data in addition to the bad (as admitted by other authors; e.g., Fordjor et al., 1983), and that in the present case this overremoval might be rather severe. Given that stress-induced breakouts and washouts may be superimposed (Plumb and Hickman, 1985; see Fig. 4), and that our 12.5-in. threshold is essentially an arbitrary one, we tested the estimate obtained above by performing the analysis again, but instead we stipulated that the smaller caliper be $<13.5 \mathrm{in}$., rather than $12.5 \mathrm{in}$. More elongation data are accepted ( $24.5 \mathrm{~m}$ for Run 1 and $18.6 \mathrm{~m}$ for Run 2), but they show a wide spread of orientations across the entire northwest quadrant, with poorly defined north and west-northwest maxima. Comparison between maximum pad azimuths from the two runs showed that differences between runs at the same depths to be significant, often up to $90^{\circ}$, when the hole eccentricity (the ratio of the calipers) is small (Fig. 6G), that is, when the borehole is nearly circular. From Figure $6 \mathrm{G}$, we argue that an eccentricity ratio of about 1.08 should be regarded as the minimum value that the FMS tool is capable of detecting reliably; therefore that it is justifiable to use it as a breakout recognition criterion in a similar manner to the 0.25 -in. caliper difference threshold applied by Plumb and Hickman (1985) and others. Application of a further filter to remove data with eccentricities less than this empirical value of 1.08 eliminates much of the scatter in maximum azimuth (Figs. 6C-6D), yielding a relatively well-defined maximum between $295^{\circ}$ and $300^{\circ}$ (Runs 1 and 2 combined; total length of breakouts 14.6 m; Fig. $6 \mathrm{H}$ ).

Well-defined breakouts were rarely seen on the FMS images (Figs. 6C-6D): on Run 1 a slight northwesterly preferred orientation was found, and a westerly direction on Run 2, but these are based upon very few observations (Run 1: $N=8$; Run 2: $N=10$ ). Although Site 838 is by some considerable margin the least well-constrained of the Leg 135 sites analyzed in this paper, we nevertheless conclude that our investigation of the Site 838 caliper data above supports our initial findings of a preferred, presumed stress-related, west-northwest borehole elongation.

\section{Site 841}

Site 841 was drilled on the inner trench slope of the Tonga forearc, just outboard of the trench-slope break, in water depths of $4810 \mathrm{~m}$. The greater part of the sedimentary section is composed of Miocene volcaniclastic turbidites, but an unconformity at 549 mbsf separates middle Miocene turbidites from lower Oligocene-middle Eocene volcaniclastic and calcareous sediments. At $602 \mathrm{mbsf}$, these sediments are in (probably normal) faulted contact with more than $200 \mathrm{~m}$ of pre- to syn-middle Eocene, rhyolitic welded tuffs. These are interpreted as subaerial deposits (Parson, Hawkins, Allan, et al., 1992) and imply that the site has suffered $5.4 \mathrm{~km}$ of subsidence since late Eocene times (Clift, this volume). A second major normal fault zone intersects the boreholes at approximately $440-480 \mathrm{mbsf}$ and omits much of the middle Miocene section. It is trench parallel and is thought to have a total trenchward displacement of hundreds of meters, possibly even up to a kilometer (MacLeod, this volume).

Poor hole conditions in the igneous basement restricted logging with the FMS to the sedimentary portions of the borehole. The principal fault zones are clearly identified on the caliper logs by rapid increases in the size of both calipers (Fig. 7B). Below the major fault zone, at approximately $470 \mathrm{mbsf}$, hole deviation increases up to a maximum of $\sim 2.5^{\circ}$ (Fig. 7A). The caliper data show that the borehole is markedly elliptical between 80 and $250 \mathrm{mbsf}$, with a larger pad azimuth consistently oriented slightly to the south of west throughout this interval (Fig. 7B). Breakouts identified on the FMS records closely track the maximum pad azimuth (Figs. 7C-7D). Unfiltered 
A.

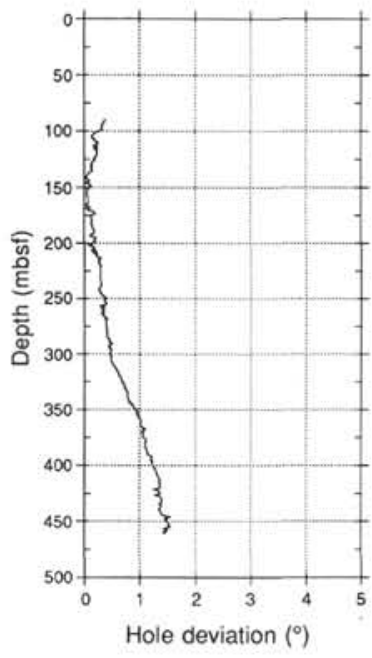

Hole 839B

Run 1

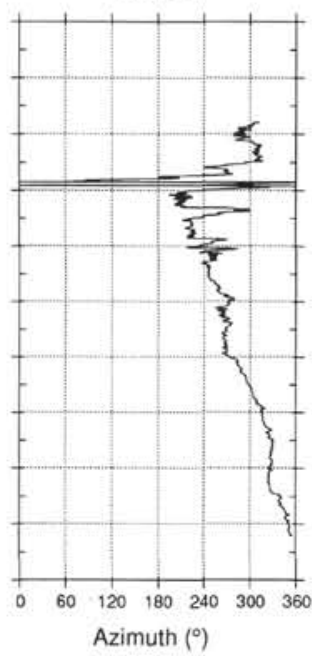

B.

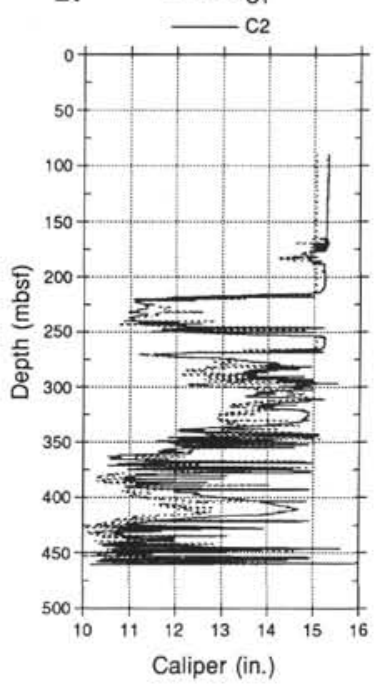

Hole 839B

Run 1

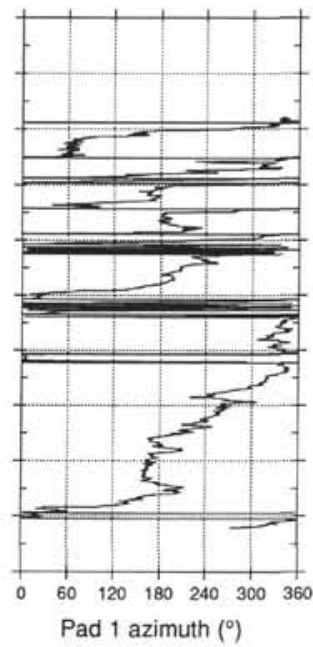

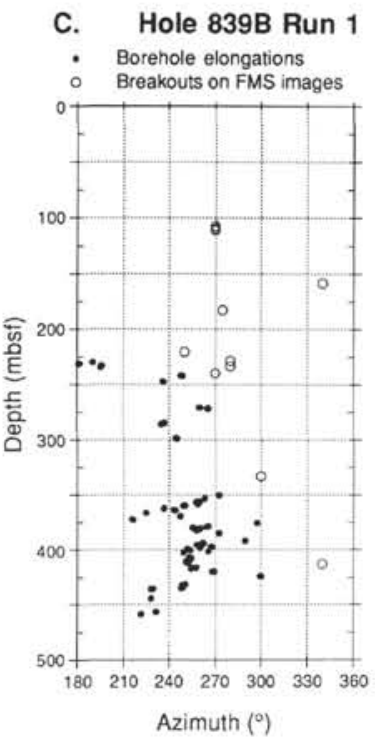

E. Site 839

Runs 1 and 2

Borehole elongation

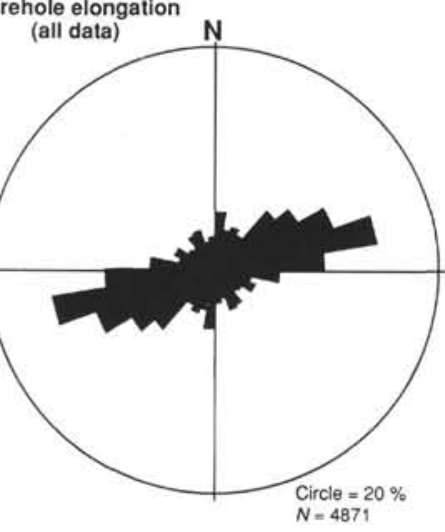

D. Hole 839 B Run 2
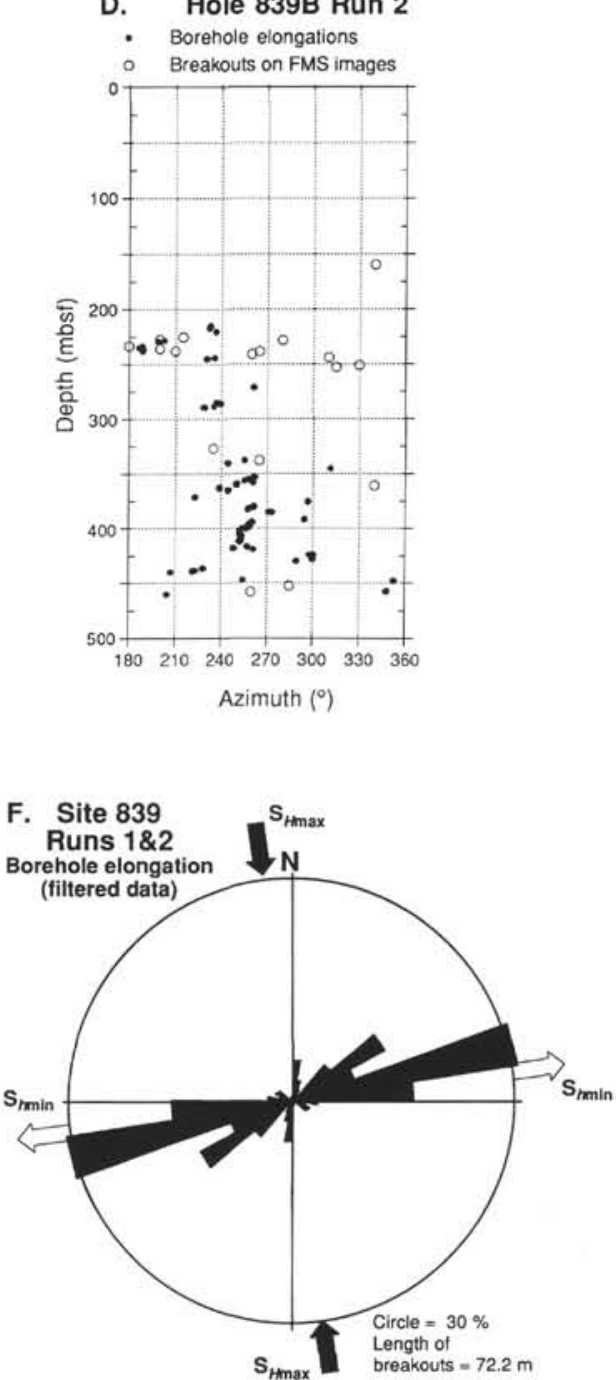

Figure 5. Borehole elongation data for Site 839. A. Hole deviation and azimuth vs. depth. B. Orthogonal calipers $\mathrm{Cl}$ and $\mathrm{C} 2$ and caliper $\mathrm{Cl}$ azimuth vs. depth, Run 1. C-D. Filtered borehole elongation directions and breakout orientations from FMS images vs. depth, Runs 1 and 2, respectively. E. Rose diagram of unfiltered borehole elongation data. $N=$ number of discrete caliper measurements, taken every $0.1524 \mathrm{~m}$ throughout the logged interval of the borehole. F. Rose diagram of borehole elongation data filtered using standard filters, with the inferred maximum and minimum in situ stress orientations indicated by the arrows. 
A.

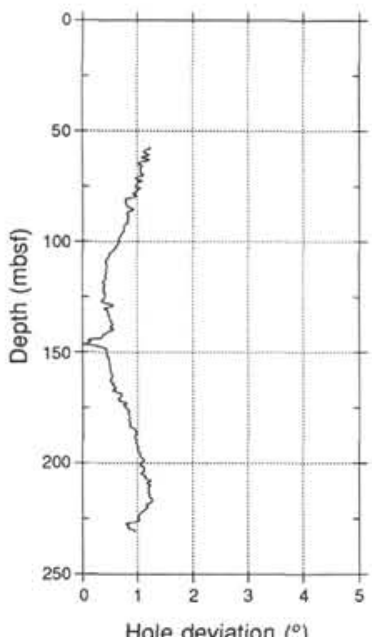

Hole deviation $\left({ }^{\circ}\right)$

D. Hole 838B Run 2

- Borehole elongations

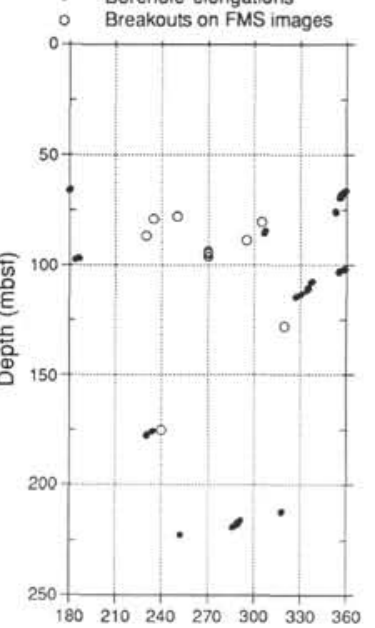

Azimuth $\left({ }^{\circ}\right)$
Hole $838 B$

Run 1

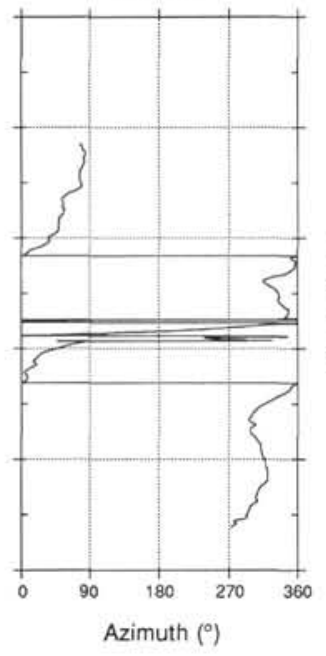

E. Site 838

Runs 1 and 2

Borehole elongation

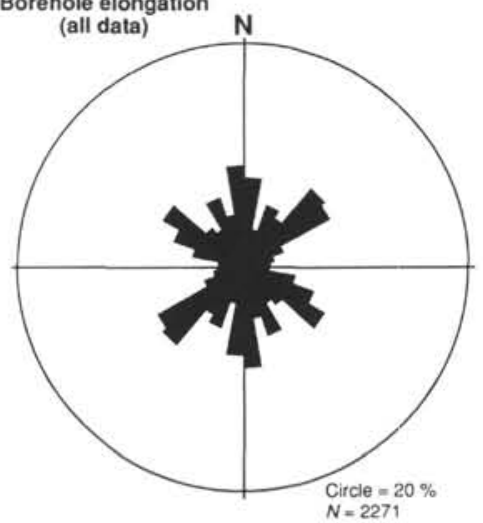

G. Run 1

- Run 2 Runs 1 and 2

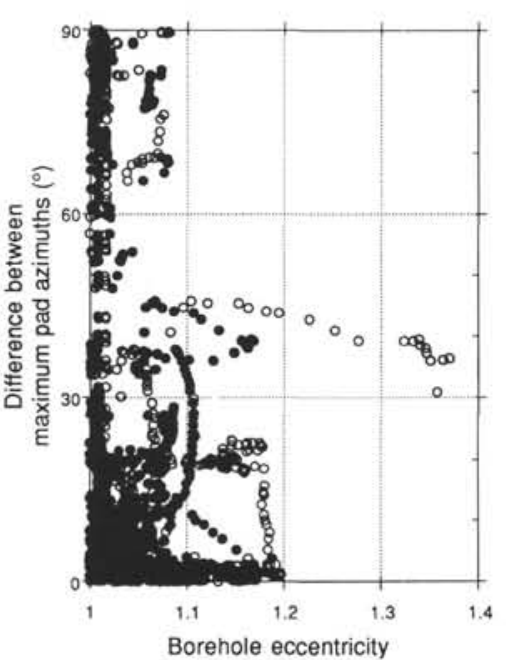

Hole 838B

Run 1

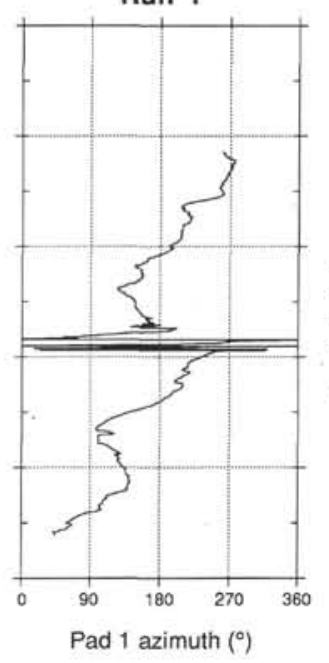

F. Site 838

Site 838
Runs $k$ and

Borehole elongation

(standard filtering)

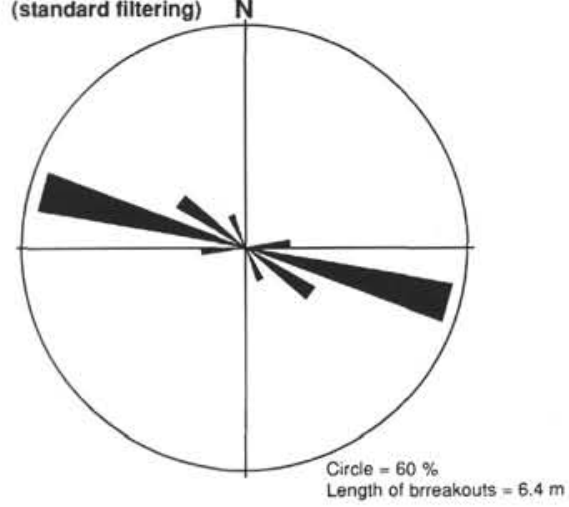

H. Site 838 Runs $1 \& 2$

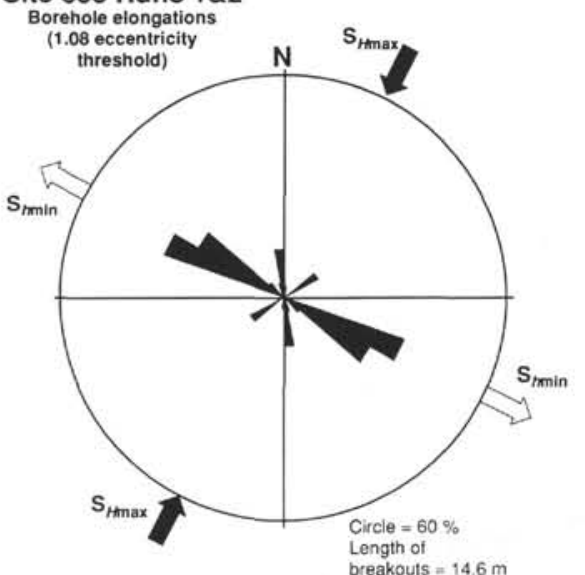

C. Hole 838B Run 1

- Borehole elongations

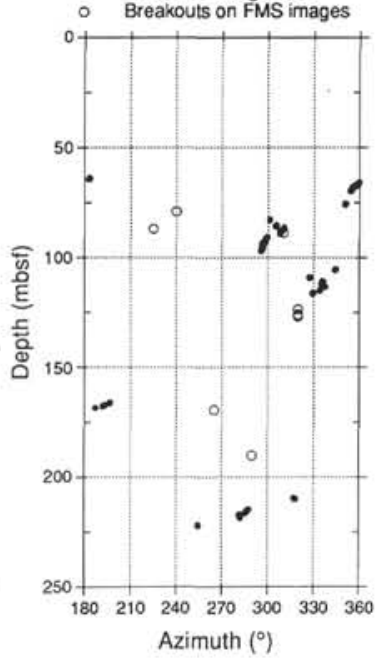

Azimuth $\left({ }^{\circ}\right)$

Figure 6. Borehole elongation data for Site 838. A. Hole deviation and azimuth vs. depth. B. Orthogonal calipers $\mathrm{C} 1$ and $\mathrm{C} 2$ and caliper $\mathrm{C} 1$ azimuth vs. depth, Run 1. C-D. Borehole elongation directions and breakout orientations from FMS images vs. depth, Runs 1 and 2, respectively, using standard filtering but with a 13.5-in. minimum caliper threshold. See text for discussion. E. Rose diagram of unfiltered borehole elongation data. $N=$ number of discrete caliper measurements, taken every $0.1524 \mathrm{~m}$ throughout the logged interval of the borehole. F. Rose diagram of borehole elongation data filtered using standard filters. Note the very small total interval of borehole that fulfills the standard recognition criteria. G. Crossplot of borehole eccentricity vs. the difference between the maximum pad azimuths on Runs 1 and 2 . Small or zero differences between maximum pad azimuths suggest that a breakout may have been encountered. Very high pad differences when the eccentricity ratio ( $=$ larger/smaller caliper) is less than about 1.08 suggest that the tool is unable to lock into breakouts reliably if the eccentricity is less than this value (i.e., in almost circular boreholes). H. Rose diagram of borehole elongation data filtered using a 13.5-in. minimum caliper threshold, and fulfilling the requirement of a caliper eccentricity of $>1.08$. The inferred maximum and minimum in situ stress orientations are indicated by the arrows. 
A.

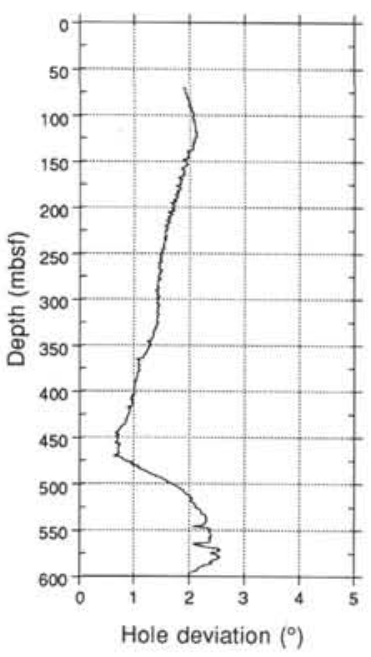

Hole 841C

Run 1

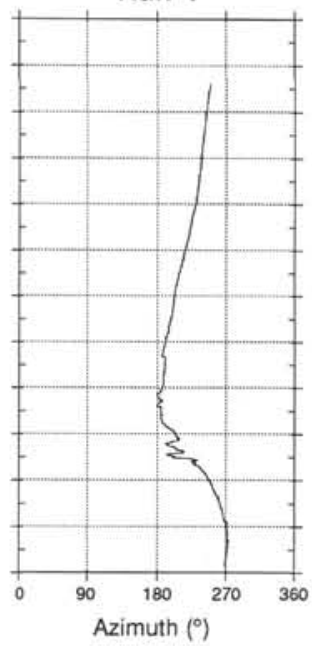

B.

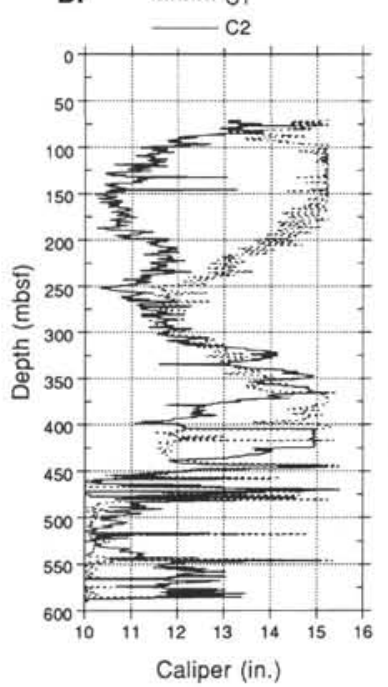

Hole $841 \mathrm{C}$

Run 1

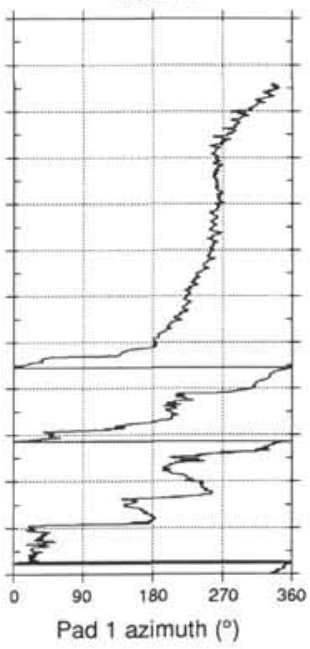

\section{Hole $841 \mathrm{C}$ Run 1}

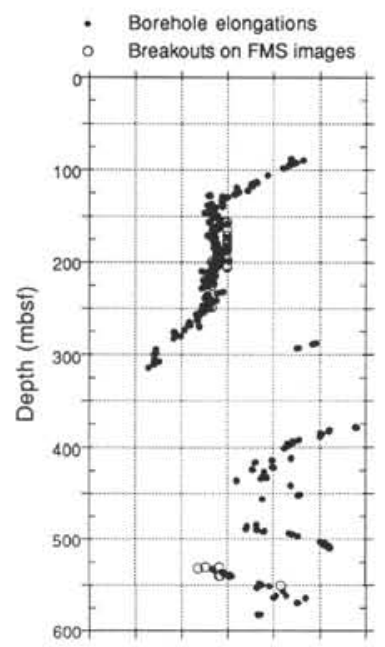

$\begin{array}{lllllll}180 & 210 & 240 & 270 & 300 & 330 & 360\end{array}$ Azimuth $\left(^{\circ}\right)$
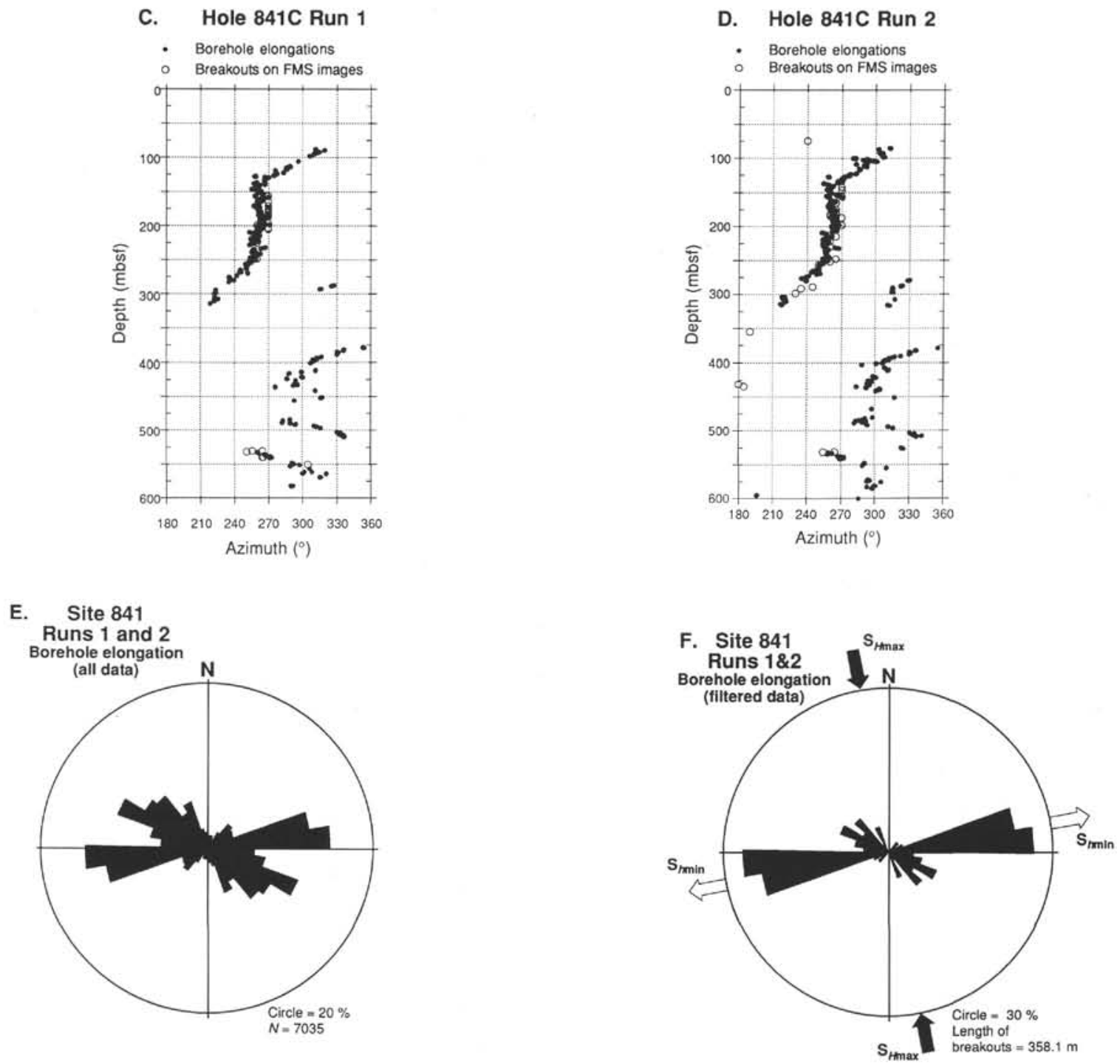

Figure 7. Borehole elongation data for Site 841 . A. Hole deviation and azimuth vs. depth. B. Orthogonal calipers $\mathrm{C} 1$ and $\mathrm{C} 2$ and caliper $\mathrm{C} 1$ azimuth vs. depth, Run 1.C-D. Filtered borehole elongation directions and breakout orientations from FMS images vs. depth, Runs I and 2, respectively. E. Rose diagram of unfiltered borehole elongation data. $N=$ number of discrete caliper measurements, taken every $0.1524 \mathrm{~m}$ throughout the logged interval of the borehole. F. Rose diagram of borehole elongation data filtered using standard filters, with the inferred maximum and minimum in situ stress orientations indicated by the arrows. 
borehole elongation data from Hole $841 \mathrm{C}$ show a principal maximum slightly to the south of west (Fig. 7E), but also a subsidiary peak trending west-northwest. Filtering of the data largely removes this latter elongation direction, to leave a well-defined maximum orientation that lies between $260^{\circ}$ and $265^{\circ}$ (Fig. 7F).

\section{Site 840}

Site 840 was drilled on the south central part of the Tonga Platform in approximately $750 \mathrm{~m}$ of water. The site lies $45 \mathrm{~km}$ east-northeast of the island of 'Ata, which forms part of the active Tofua island-arc chain. Some $597 \mathrm{~m}$ of upper Miocene to Holocene volcaniclastic and carbonate sediments were drilled; logging included one pass of the FMS between 87 and 516 mbsf (named Run 2 here) and a repeat pass (Run 1) between 433 and 530 mbsf. Hole deviation was less than $2^{\circ}$ throughout (Fig. 8A). Above 250 mbsf the greater part of the borehole is at or greater than the maximum caliper extent, and much of the rest of the Hole 840B appears to be near circular (Fig. 8B). Unfiltered borehole elongations show a bimodal distribution, with north and west-northwest maxima (Fig. 8E). Standard filtering of the data reduces the northerly peak slightly (Fig. $8 \mathrm{~F}$ ), but does not eliminate it entirely; however, reference to the degree of ellipticity of the borehole (Fig. 8D) shows the northerly elongation direction to be restricted to one section of the borehole only $(\sim 450-500 \mathrm{mbsf})$, and that this section is virtually circular (i.e., the ratio of larger to smaller caliper there is less than 1.04). The west-northwest elongations, in contrast, are associated with sections of the borehole that are far more elliptical (Fig. 8C). We therefore favor the west-northwest direction (maximum orientation between $280^{\circ}$ and $285^{\circ}$ ) as the most likely to reflect the regional in situ $S_{i m \text { min }}$ stress direction. This is supported by the predominant west-northwest to northwest azimuth of breakouts identified on the FMS records from Hole 840B (Fig. 8C).

\section{DISCUSSION}

The FMS caliper data, backed up by observation of breakouts on the FMS images, have enabled us to isolate a preferred borehole elongation direction for each of the six sites logged on Leg 135. Before equating these elongations with regional, far-field, in situ stress directions, however, one should note that breakout directions determined using criteria such as those adopted here need not necessarily be of regional significance. Stress trajectories may be deflected around free surfaces such as fault planes (Chinnery, 1966), and many actual examples have been reported of, for example, deviation of the $S_{h \min }$ minimum horizontal compressive stress direction toward parallelism with the strike of a nearby fault (e.g., Bell, 1990). This is by no means a universal effect, depending upon whether the fault is "locked" or acting as a free surface. Also of significance is the observation that near-surface, in situ stresses are often anomalous in their magnitudes and/or directions (Engelder and Sbar, 1984), again presumably because of the "free surface" effect; in consequence, stress determinations at shallow depths within boreholes (sometimes as much as $150 \mathrm{~m}$; R. Brereton, pers. comm., 1992) may not be representative of the regional in situ stress direction.

The local in situ crustal stresses at each site, as determined from the borehole elongation directions, are internally relatively consistent, with the possible exception of Site 838. The elongation directions, here equated to the minimum horizontal compressive stress $S_{h \min }$, are given in Table 1. The direction of maximum compressive stress $S_{H \max }$, which is perpendicular to $S_{h \min }$, is plotted for each site on Figure 2. A relatively consistent, approximately northerly $S_{H \max }$ direction is obtained from Sites 838 to 841 ; in marked contrast, a near westerly maximum compressive stress direction is found for Sites 834-835.

It is difficult to assess with any degree of certainty (with the relatively small number of sites investigated) whether this change of $S_{H \max }$ orientation has regional geological significance, or whether some of the sites have been affected by local free-surface effects. Sites
Table 1. Summary of borehole elongation directions from Leg 135 boreholes as deduced in this study.

\begin{tabular}{rrcccc}
\hline Site & $\begin{array}{c}\text { Length } \\
(\mathrm{m})\end{array}$ & Mode & Mean & $\begin{array}{c}\text { Ang. } \\
\text { dev. }\end{array}$ & Quality \\
\hline 834 & 202.2 & $195^{\circ}-200^{\circ}$ & $200.6^{\circ}$ & $27.5^{\circ}$ & $\mathrm{B}$ \\
835 & 112.2 & $330^{\circ}-335^{\circ}$ & $329.9^{\circ}$ & $7.5^{\circ}$ & $\mathrm{A}$ \\
838 & 14.9 & $295^{\circ}-300^{\circ}$ & $311.2^{\circ}$ & $31.0^{\circ}$ & $\mathrm{D}$ \\
839 & 72.2 & $255^{\circ}-260^{\circ}$ & $249.5^{\circ}$ & $25.5^{\circ}$ & $\mathrm{C}$ \\
840 & 68.7 & $280^{\circ}-285^{\circ}$ & $296.3^{\circ}$ & $34.9^{\circ}$ & $\mathrm{C}$ \\
841 & 358.1 & $260^{\circ}-265^{\circ}$ & $272.9^{\circ}$ & $27.3^{\circ}$ & A
\end{tabular}

Notes: Borehole elongation directions are equated to the minimum horizontal compressive stress $S_{h \min }$. The quality ranking follows the convention adopted by Zoback (1992) for the World Stress Map Project and is dependent upon the total length of the breakouts and/or their standard deviations. Length $=$ total length of the borehole from the two FMS passes that satisfies the breakout criteria defined here. Ang. dev. $=$ angular deviation.

most likely to have been affected are those with very shallow penetration and/or whose borehole elongation direction parallels the predominant structural orientation in the vicinity of the site. Despite its internal consistency Site 835 fulfills both of these conditions: virtually all of the eligible borehole elongations lie at depths of less than $150 \mathrm{~m}$ (Figs. $3 \mathrm{C}-3 \mathrm{D})$, and the elongation direction is almost parallel to the strike of the fault-bounded sub-basin within which it is situated. Seismic records show these normal faults to have been recently active (Parson et al., this volume). For Site 834 the elongation direction is also parallel to the active, sub-basin bounding normal faults close to the site (Parson et al., this volume); the breakouts at the site, however, do mostly lie at depths $>150 \mathrm{~m}$ (Figs. 4C-4D). None of the other boreholes have preferred elongation directions parallel to their local structural trends; we do note, however, that Site 838 is relatively shallow.

Despite the above uncertainties, it is still eminently possible that all of the borehole elongations deduced from the six sites indeed relate to regionally significant in situ stress direction. Our near east-west $S_{h \text { min }}$, in situ stress directions from Sites 838 to 841 at least are in agreement with the observation of recent trench-parallel normal faulting across the Tonga Ridge (both the forearc platform and inner wall of the trench; e.g., Herzer and Exon, 1985; Parson, Hawkins, Allan, et al., 1992; MacLeod, this volume; MacLeod and Lothian, this volume), and with seismic focal mechanism studies (indicating trench-normal tension axes in the central Lau Basin and, in places, the Tonga Ridge: Hamburger and Isacks, 1988; Pelletier and Louat, 1989). This implies that, for these sites, $S_{H \max }$ can be correlated with $\sigma_{2}$ and $S_{h \min }$ with $\sigma_{3}$.

The near westerly $S_{H \max }$ directions from Sites 834 and 835 are slightly harder to explain and are more likely to be related to anomalous local stresses. If of regional significance, they may conceivably be influenced by the closer proximity of these sites to the complexities of the trench-trench transform system that lies to the north of Fiji and the Lau Basin; alternatively, they are of the correct orientation to be related to a component of ridge push (e.g., Hager, 1978; Parsons and Richter, 1980) from the nearby, vigorously spreading Central Lau Spreading Center.

Forearc-arc-backarc systems are exceedingly complex geodynamic environments, and systematic changes in the orientation of the maximum horizontal compressive stress direction in the overriding plate with distance from the trench have also been reported from several other subduction zones (Japan, Aleutians, Hellenic Arc: Nakamura and Uyeda, 1980; Izu-Bonin Arc: Pezard et al., 1992). In these systems, however, the compressive stress $S_{H \max }$ changes from being approximately perpendicular to the trench in the forearc to being parallel to the trench in the volcanic arc and backarc (i.e., changing from compression across the forearc to extension across the backarc). This is the exact opposite to our findings from the Tonga-Lau system.

Finite element modeling, however (Bott et al., 1989; Whittaker et al., 1992), has shown that conditions of either compression or exten- 
A.

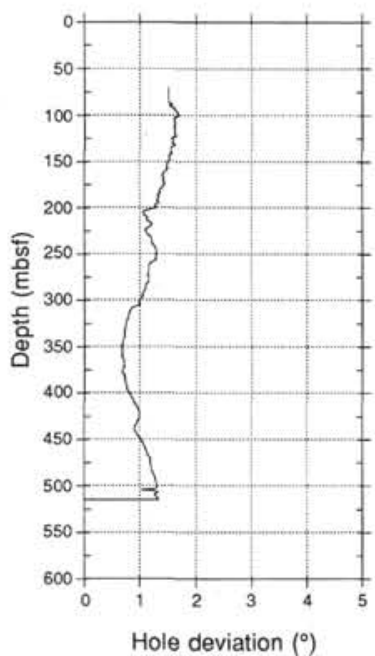

Hole 840B

Run 2

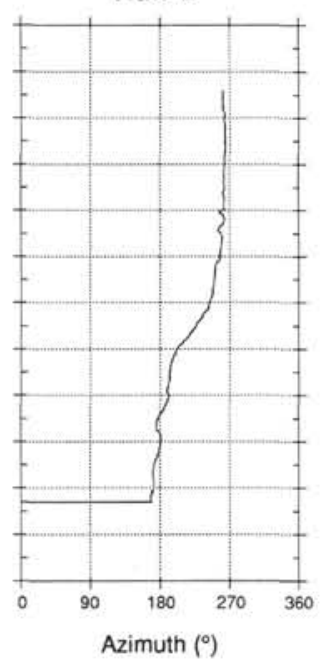

Azimuth $\left({ }^{\circ}\right)$
B.

C1

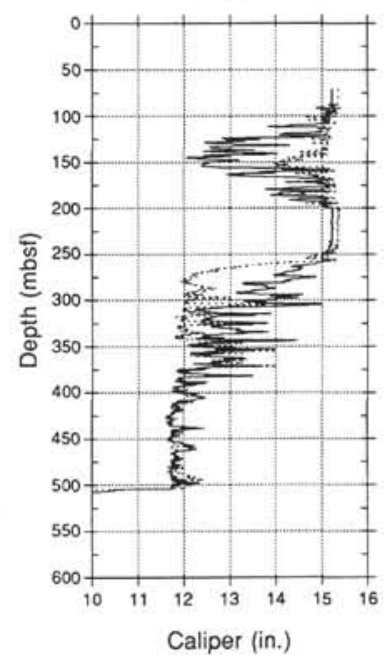

Hole $840 \mathrm{~B}$

Run 2

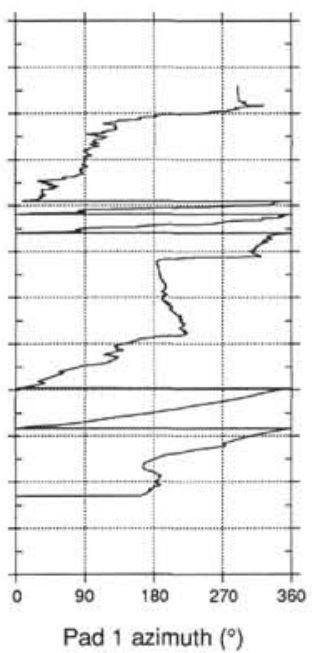

C. Hole 840 B Runs 1 and 2

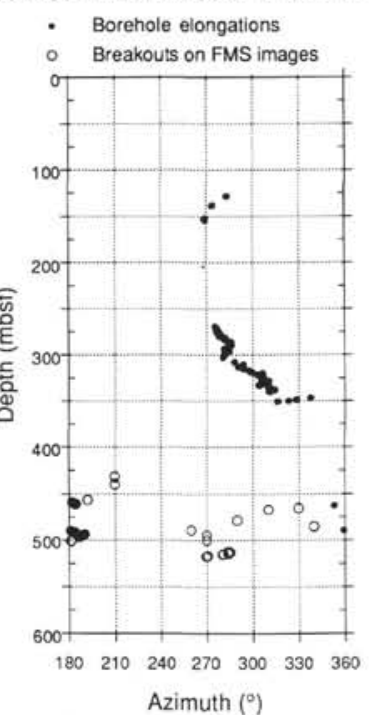

E. Site 840

Runs 1 and 2

Borehole elongation

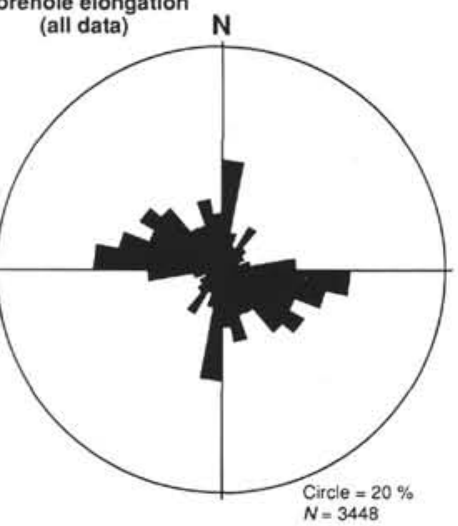

D.
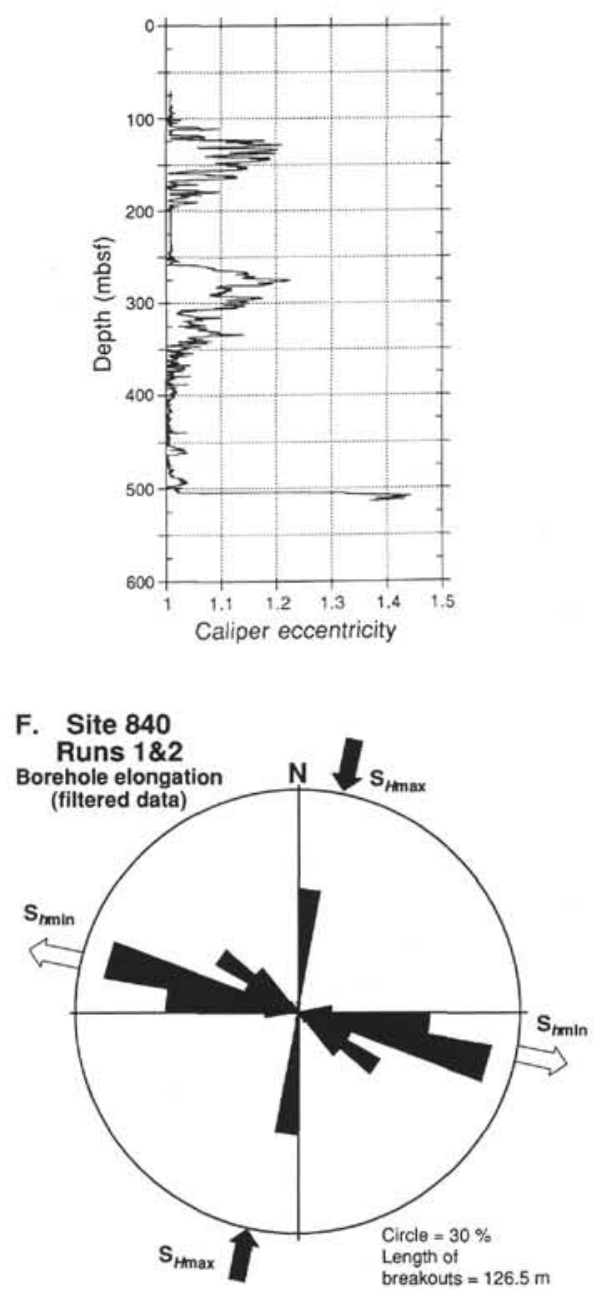

Figure 8. Borehole elongation data for Site 840. A. Hole deviation and azimuth vs. depth. B. Orthogonal calipers $\mathrm{Cl}$ and $\mathrm{C} 2$ and caliper $\mathrm{Cl}$ azimuth vs. depth, Run 1. C. Filtered borehole elongation directions and breakout orientations from FMS images vs. depth, Runs 1 and 2 combined. D. Borehole eccentricity vs. depth. The north-south subsidiary maximum direction isolated by standard filtering (Fig. $8 \mathrm{~F}$ ) is shown here to correspond to intervals of extremely low eccentricity ( $\leq-1.04)$ between 450 and 500 mbsf. The west to northwest maximum, therefore, is thought more likely to correspond to the regional stress field. See text for discussion. E. Rose diagram of unfiltered borehole elongation data. $N=$ number of discrete caliper measurements, taken every $0.1524 \mathrm{~m}$ throughout the logged interval of the borehole. F. Rose diagram of borehole elongation data filtered using standard filters, with the inferred maximum and minimum in situ stress orientations indicated by the arrows. 
sion can exist in the trench-arc system, depending upon whether the principal subduction fault plane is locked or unlocked (i.e., acting as a weak surface). If some intermediate state exists, that is, if a limited amount of stress can be transmitted across the subduction fault, a stress gradient from compressional in the forearc to extensional in the backarc can be established. Still further complexities are introduced when the ridge push forces from active backarc spreading axes (Whittaker et al., 1992) and forces arising from the effects of arc topography (Froidevaux et al., 1988) are considered.

We suggest that the disparity between our results (showing extension across the Tonga forearc) and those of Nakamura and Uyeda (1980) is a consequence of the differences between the subduction dynamics of the Japan/Aleutian/Hellenic systems and those of the Tonga subduction zone. It has long been recognized that great variety exists in the deformation and accretionary styles between different subduction zones, a complete continuum existing between those dominated by compression in the overriding plate and those dominated by extension (Uyeda and Kanamori, 1979). Jarrard (1986) showed that the stresses and strains in such environments are controlled by a mixture of parameters, including the convergence rate, age of the subducting slab, and the dip of the slab at shallow levels beneath the arc. The Tonga system falls in Jarrard's most extension-dominated category: subduction of an old, steeply dipping slab causes rapid retreat or rollback of the trench axis, consequently inducing widespread extension in the overriding plate and gravitational collapse of the forearc in a trenchward direction. In such a scenario there is little mechanical coupling at the plate boundary (i.e., the subduction fault is unlocked: Froidevaux et al., 1988; Whittaker et al., 1992), and the compressional stresses generated by plate convergence are not transmitted far into the overriding plate. The Japanese and Aleutian subduction zones, in contrast, fall toward the compressional end of Jarrard's strain categories, with shallower and more buoyant slabs allowing more stress transmission into the forearc, and the subduction fault probably acting as a partially or intermittently locked surface. The most compressional subduction zones of all, such as the Peru and Chile trenches, are compressive throughout and no rotation of the stress regime is reported (Zoback, 1992); for these systems, mechanical coupling between the plates is very strong and the subduction fault is probably completely locked except at the moment of failure.

\section{CONCLUSIONS}

Estimates of the directions of the horizontal in situ stresses in the Lau backarc basin and Tonga forearc have been made from an evaluation of FMS caliper data from six sites drilled during Leg 135. Variations in the maximum stress direction thus obtained show that stress gradients may exist across the Tonga/Lau forearc-arc-backarcremnant arc system, as postulated for other subduction zones by Nakamura and Uyeda (1980). Breakout data analyzed from four sites show that, up to a distance of at least $300 \mathrm{~km}$ from the axis of the Tonga Trench, the maximum horizontal compressive stress direction is near trench-parallel; in other words, that the extension direction is approximately perpendicular to the trench. This result corroborates earthquake focal mechanism, seismic, and structural evidence that the forearc is actively extending on (predominantly) trench-parallel structures; furthermore, it suggests that the principal interplate subduction fault is acting as a weak surface, such that compressive stresses arising from plate convergence are not being transmitted into the overriding plate.

The two sites drilled in the northwestern part of the Lau Basin, in contrast, show a near east-west maximum horizontal compression direction. We cannot be sure that these directions do not relate to local perturbations of the regional stress field. If they are of regional significance, then they may be influenced by ridge push forces from the Central Lau Spreading Center and/or by complexities resulting from the diffuse intraplate deformation associated with the trenchtrench transform zone lying to the north of Fiji.

\section{ACKNOWLEDGMENTS}

We would like to thank Lindsay Parson and Robin Brereton for helpful reviews of this manuscript. C.J.M. acknowledges with gratitude financial support from the Natural Environment Research Council, and Lin Kay for smoothing the way.

\section{REFERENCES ${ }^{\circ}$}

Babcock, E.A., 1978. Measurement of subsurface fractures from dipmeter logs. AAPG Bull., 62:1111-1126.

Bell, J.S., 1990. Investigating stress regimes in sedimentary basins using information from oil industry wireline logs and drilling records. In Hurst, A., Lovell, M.A., and Morton, A.C. (Eds.), Geological Applications of Wireline Logs. Geol. Soc. Spec. Publ. London, 48:305-325.

Bell, J.S., and Gough, D.I., 1979. Northeast-southwest compressive stress in Alberta: evidence from oil wells. Earth Planet. Sci. Lett., 45:475-482. 1983. The use of borehole breakouts in the study of crustal stress. In Zoback, M.D., and Haimson, B.C. (Eds.), Hydraulic Fracturing Stress Measurements: Washington (National Academy Press), 201-209.

Bott, M.H.P., Waghom, G.D., and Whittaker, A., 1989. Plate boundary forces at subduction zones and trench-arc compression. Tectonophysics, 170:1-15.

Chinnery, M.A., 1966. Secondary faulting. Can. J. Earth Sci., 3:169-190.

Collier, J., and Sinha, M., 1990. Seismic images of a magma chamber beneath the Lau Basin back-arc spreading center. Nature, 346:646-648.

Ekstrom, M.P., Dahan, C., Chen, M.-Y., Lloyd, P., and Rossi, D.J., 1987. Formation imaging with microelectrical scanning arrays. Log Analyst, 28:294-306.

Engelder, T., and Sbar, M.L., 1984. Near-surface in situ stress: introduction. J. Geophys. Res., 89:9321-9322.

Evans, C.J., and Brereton, N.R., 1990. In situ crustal stress in the United Kingdom from borehole breakouts. In Hurst, A., Lovell, M.A., and Morton, A.C. (Eds.), Geological Applications of Wireline Logs. Geol. Soc. Spec. Publ. London, 48:327-338.

Fordjor, C.K., Bell. J.S., and Gough, D.I., 1983. Breakouts in Alberta and stress in the North American plate. Can. J. Earth Sci., 20:1445-1455.

Froidevaux, C., Uyeda, S., and Uyeshima, M., 1988. Island arc tectonics. Tectonophysics, 148:1-9.

Gough, D.I., 1984. Mantle upflow under North America and plate dynamics. Nature, 311:428-433.

Gough, D.I., and Bell, J.S., 1981. Stress orientations from oil well fractures in Alberta and Texas. Can. J. Earth Sci., 18:638-645.

Hager, B.H., 1978. Oceanic plate motions driven by lithospheric thickening and subducted slabs. Nature, 276:156-159.

Haimson, B.C., and Fairhurst, C., 1967. Initiation and extension of hydraulic fractures in rocks. Soc. Pet. Eng. J., 7:310-318.

-1970 . In situ stress determination at great depth by means of fracturing. In Somerton, W. (Ed.), 1lth Symposium on Rock Mechanics. Soc. Min. Eng. AIME, 559-584.

Haimson, B.C., and Herrick, C.G., 1986. Borehole breakouts-a new tool for estimating in situ stress? In Stephansson. O. (Ed.), Proc. International Symp. on Rock Stress and Rock Stress Measurements, Stockholm, Sweden, 387-396.

Hamburger, M.W., and Isacks, B.L., 1988. Diffuse back-arc deformation in the southwestern Pacific, Nature, 332:599-604.

Herzer, R.H., and Exon, N.F., 1985. Structure and basin analysis of the southern Tonga forearc. In Scholl, D.W., and Vallier, T.L. (Eds.), Geology and Offshore Resources of Pacific Island Arcs-Tonga Region. CircumPac. Counc. Energy Miner. Resour., Earth Sci. Ser., 2:55-73.

Hickman, S.H., Healy, J.H., and Zoback, M.D., 1985. In situ stress, natural fracture distribution, and borehole elongation in the Auburn Geothermal Well, Auburn, New York. J. Geophys. Res., 90:5497-5512.

Jarrard, R.D., 1986. Causes of compression and extension behind trenches. Tectonophysics, 132:89-102.

MacLeod, C.J., Parson, L.M., Sager, W.W., and the ODP Leg 135 Scientific Party, 1992. Identification of tectonic rotations in boreholes by the integration of core information with Formation MicroScanner and Borehole Televiewer images. In Hurst, A., Griffiths, C.M., and Worthington, P.F.

\footnotetext{
"Abbreviations for names of organizations and publication titles in ODP reference lists follow the style given in Chemical Abstracts Service Source Index (published by American Chemical Society).
} 
(Eds.) Geological Applications of Wireline Logs II. Geol. Soc. Spec. Publ. London, 65:235-246.

Moos, D., and Zoback, M.D.. 1990. Utilization of observations of well bore failure to constrain the orientation and magnitude of crustal stresses: application to continental, Deep Sea Drilling Project, and Ocean Drilling Program boreholes. J. Geophys. Res., 95:9305-9325.

Nakamura, K., and Uyeda, S., 1980. Stress gradient in arc-back arc regions and plate subduction. J. Geophys. Res., 85:6419-6428.

Parson, L., Hawkins, J., Allan, J., et al., 1992. Proc. ODP, Init. Repts., 135: College Station. TX (Ocean Drilling Program).

Parson, L.M., Pearce, J.A., Murton, B.J., Hodkinson, R.A., Bloomer, S., Ernewein, M., Huggett, Q.J., Miller, S., Johnson, L., Rodda, P., and Helu, S., 1990. Role of ridge jumps and ridge propagation in the tectonic evolution of the Lau back-arc basin, southwest Pacific. Geology, 18:470-473.

Parsons, B., and Richter, F.M., 1980. A relation between the driving force and geoid anomaly associated with mid-ocean ridges. Earth Planet. Sci. Lett., 51:445-450.

Pelletier, B., and Louat, R., 1989. Seismotectonics and present day relative plate motions in the Tonga-Lau and Kermadec-Havre region. Tectonophysics, 165:237-250.

Pezard, P.A., Hiscott, R.N., Lovell, M.A., Collela, A., and Malinverno, A.. 1992. Evolution of the Izu-Bonin intraoceanic forearc basin, western Pacific, from cores and FMS images. In Hurst, A., Griffiths, C.M., and Worthington, P.F. (Eds.), Geological Applications of Wireline Logs II. Geol. Soc. Spec. Publ. London, 65:43-69.

Plumb, R.A., and Hickman, S.H., 1985. Stress-induced borehole elongation: a comparison between the four-arm dipmeter and the Borehole Televiewer in the Auburn geothermal well. J. Geophys. Res., 90:5513-5521.

Springer, J.E., 1987. Stress orientations from well bore breakouts in the Coalinga region. Tectonics, 6:667-676.
Tappin. D.R., Herzer, R.H., and Stevenson, A.J., 1992. Structure and history of an oceanic forearc- the Tonga Ridge $22^{\circ}$ to $26^{\circ}$ South. In Ballance, P.F., Herzer, R.H., and Stevenson, A.J. (Eds.), Geology and Resources of Island Arcs, Tonga-Lau-Fiji Region: Berlin (Springer-Verlag).

Uyeda, S., and Kanamori, H., 1979. Back-arc opening and the mode of subduction. J. Geophys. Res., 84:1049-1061.

Vernik. L., and Zoback, M.D., 1992. Estimation of maximum horizontal principal stress magnitude from stress-induced well bore breakouts in the Cajon Pass Scientific Research Borehole. J. Geophys. Res., 97:5109-5119.

Whittaker, A., Bott, M.H.P., and Waghorn, G.D.. 1992. Stresses and plate boundary forces associated with subduction plate margins. J. Geophys. Res., 11933-11944.

Zemanek. J., Glenn, E.E., Norton, L.J., and Caldwell, R.L., 1970. Formation evaluation by inspection with the borehole televiewer. Geophysics, 35:254-269.

Zoback, M.D., and Healy, J.H., 1992. In situ stress measurements to $3.5 \mathrm{~km}$ depth in the Cajon Pass Scientific Research Borehole. J. Geophys. Res., 97:5039-5057.

Zoback, M.D., Moos, D., Mastin, L., and Anderson, R.N., 1985. Well bore breakouts and in situ stress. J. Geophys. Res, 90:5523-5530.

Zoback, M.L., 1992. First- and second-order patterns of stress in the lithosphere: the world stress map project. J. Geophys. Res., 97:11703-11728.

Zoback, M.L., and Zoback, M.D., 1980. State of stress in the conterminous U.S. J. Geophys. Res., 85:6113-6156.

Date of initial receipt: 2 July 1992

Date of acceptance: 28 July 1993

Ms 135SR-159 